\title{
Work Life Balance and Job Satisfaction among the Working Women of Banking and Education Sector - A Comparative Study
}

\author{
Rajesh K. Yadav*, Nishant Dabhade** \\ Department of Management, RKDF College of Engineering, Bhopal (M.P.), India \\ *,**E-mail address: drrajeshkyadav@yahoo.com , nishant.dabhade.mgmt@gmail.com
}

\begin{abstract}
In the present scenario, work life balance for women employees is highly desirable and if there is no job satisfaction and consistency in life, it can create a dilemma for working women. Work life balance requires attaining equilibrium between professional work and personal work, so that it reduces friction between official and domestic life. The ultimate performance of any organization depends on the performance of its employees, which in turn depends on numerous factors. These factors can be related to job satisfaction or family or both. A comparative study is conducted among the working women of some Govt. colleges and national institutes of Bhopal in education sector and nationalized banks, running their in Bhopal (M.P.) for banking sector. The objective of this research is to study the working environment and women's perception about the work life balance and job satisfaction, who are working in banking and education sector. Apart from it, another significant objective is to study effects of work life balance on job satisfaction and initiatives taken by the organizations for effective work life balance and its relation with the job satisfaction. Standard Deviation is applied in this paper to check the authenticity of data given by the respondents of both the sectors. Finding suggests that WLB can be achieved by the factors responsible for job satisfaction such as: supportive colleagues, supportive working conditions, mentally challenging work, equitable rewards and employee oriented policies etc.
\end{abstract}

Keywords: Family; Employee's satisfaction; Job; Performance; Productivity and Rewards etc.

\section{INTRODUCTION}

In India the concern over work-life balance is gradually becoming a common talk especially for women employees. Work life balance is a state of equilibrium in which the demand of both professional and personal life is equal. Each role having different set of demands and when such role demands overlap, multiple problems are faced. In reality life and work over-lap and interact. In designing the work life policies, employer should think that the commitment of employees can make the difference between those companies which compete at the marketplace and those which cannot. A balanced life for women is one where they spread their energy and effort between key areas of importance.

This study investigates the factors responsible for work life balance and job satisfaction level amongst the women employees working in banking and education sector. Employees are greatest resource of an organization. Attracting and retaining the right people is critical to the 
success of an organization. When it comes to human environment, it focuses on human aspects that influence an employee's performance and job satisfaction. Job satisfaction has been defined as the degree to which employees have a positive \& effective orientation towards employment by the organization. Work determines a person's worth and place in society and it influences one's psychological identity and sense of well being. The term "work" is being used to paid work or employment. Work establishes one in the community of human kind. It links a person to others, advances the goals of culture, and gives purpose to one's existence. Work is a purposeful human activity which is directed toward the satisfaction of human needs and desires. It is obvious that work needs to be satisfying the job for a mutual beneficial relationship between employee and employer. Job satisfaction creates innovative ideas among the employees. Individuals may become more loyal towards the organization. Employees will be more satisfied if they get what they expected with efficient work life balance. This study shows the factors affecting work life balance and job satisfaction level of women employees working in banking and education sector in Bhopal. Logically it is the satisfied worker who shows the maximum effectiveness and efficiency in his work $[4,11,12]$.

\section{DOES WORK LIFE BALANCE AND JOB SATISFACTION MATTERS TO THE WOMEN EMPLOYEES}

The working sphere of Women in India is changing at incredible pace due to progressive reduction in trade barriers, modern innovation in technologies, globally interconnected market place, cut throat competition and business rivalry and changing family and population patterns. These factors bring out tense anxiety into the life of the women and then it is magnified many times if both the husband-wife work and they have children of growing age and old age parents. This constant worry can cause disorder on the psychological comfort of the women due to a feeling of diminished control over one's life and a hopeless perception that there is never enough time to have a sensible stability and balance in life. Apart from it there are a variety of factors that make women employee feel positive or negative about their job. Moreover, some employees may be satisfied with a few aspects of their work but dissatisfied with all other aspects. Factors that lead to hold positive or negative perceptions of their job have their own impact on work life balance. This mental stress for women can lead to physical stress and cause ill health, headache, gastritis, body ache, de-motivation, low morale etc., lead to long term cardiac problems, high blood pressure, diabetes or other psychiatric problems and low job performance etc. All these problems generate Work life conflict and job dissatisfaction especially for women employees, which results in:

- Increased Absenteeism

- Increased Employee Turnover

- Reduced Productivity

- Reduced Job Satisfaction

- Increased Managerial Stress

- Damage of Family and Social relationship

A positive and healthy employee oriented culture translates into increased job satisfaction and productivity while work life imbalance causes relationship degradation and job dissatisfaction for women employees because working too much may cause women to miss family interactions as well as important events. Relationships require nurturing, time and 
ongoing attention. Once damage is done, it is often more difficult and time consuming to repair $[6,13,15,16-20]$.

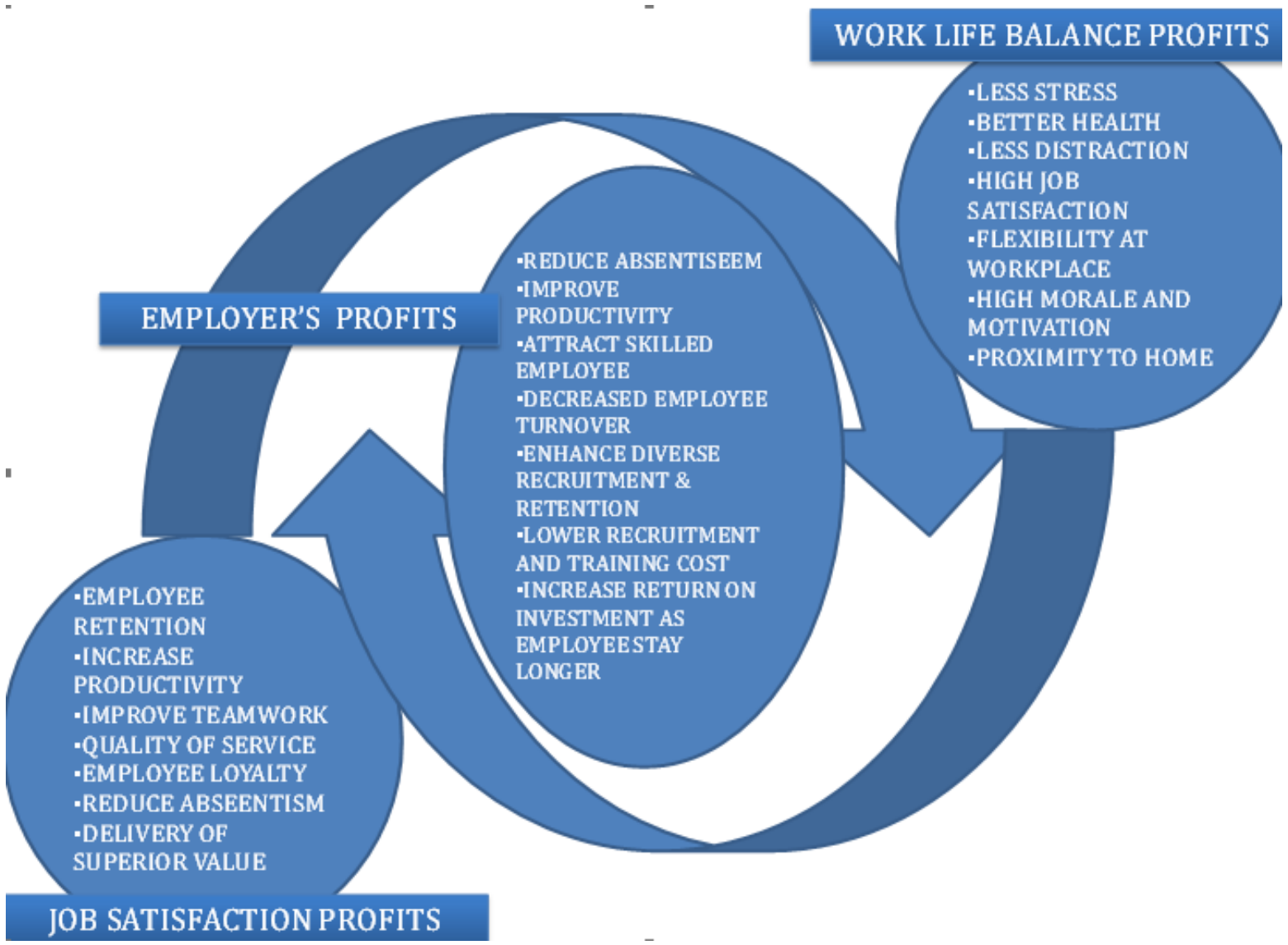

Figure 1. Profits of WLB and Job Satisfaction.

\section{EFFECTS OF WORK LIFE BALANCE AND JOB SATISFACTION}

- Workers Punctuality, Teamwork, Customer service, work supervision responsibility, group behavior, peer interaction and leadership initiative by workers are reduced.

- Recognition is the part of job satisfaction. It is an act of notice, praise, or blame supplied by one or more superiors, peer, colleague, management person, client, and/or the general public. Failure in getting recognition leads to poor job satisfaction.

- Creativity, new job-expertise learning and innovation of worker are grossly damaged due to lowering of work related enthusiasm among workers.

- Seniority demands the promotion and promotion facilitates mental satisfaction. It refers to designate an actual change in upward direction in job status. The promotion to the next level will result in positive changes such as pay, autonomy and supervision etc.

- Workers having problem balancing work roles and family roles, set bad standard in the company work setting and often upset the friendly work ambience.

- Highest monetary satisfaction for specially women employee is monthly salary or pay. These are the sequences of events in which compensation plays a major role. There is no 
doubt that monetary rewards may play a very influential role in determining job satisfaction. If salaries are not market oriented, this can lead to dissatisfaction.

- Workers problems get reflected negatively on company's turnover, operating profit and balance sheet.

- Women employees facilitate stress on interpersonal relationship within the premises majorly with the female colleagues; it involves relationships with superiors, subordinates, and peers or colleague. If the employee experiences the healthy relationship with others within the organization, so it will boost the morale and satisfaction toward the job and lead to the higher productivity.

- Substantial increase in the cases of workers being absent on the job and in extreme cases leaving the job.

- Physical working conditions and facilities are equally significant for job satisfaction of women employees. Apart from this company policy and administration plays an important role in satisfaction. These should be framed in keeping the view of employee's needs and desire $[5,7,9]$.

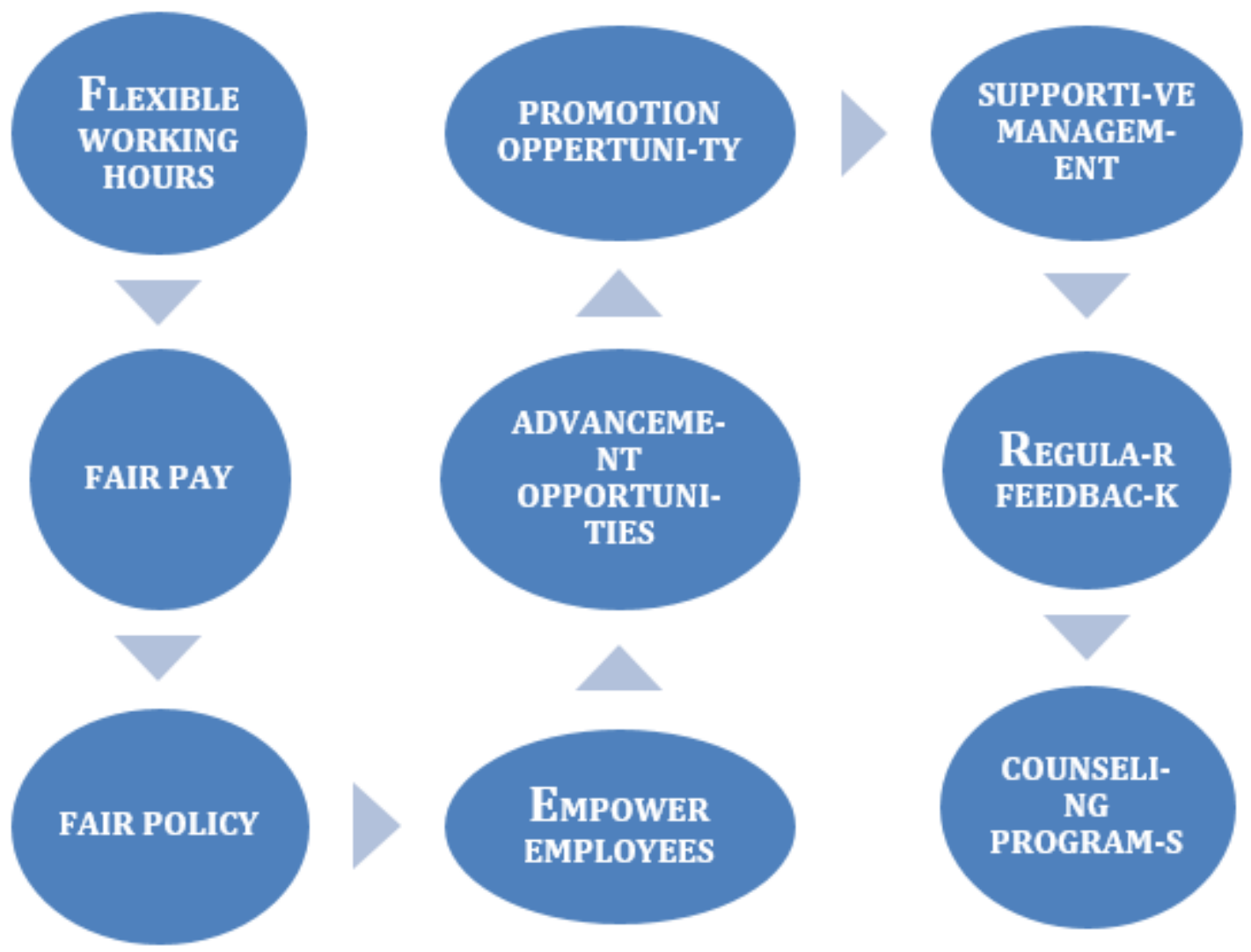

Figure 2. Some Approaches to improve WLB and Job Satisfaction. 


\section{RATIONALE OF THE STUDY}

When satisfaction from job and work-life balance is achieved, people feel that they have attained the best possible quality of life. Work-life balance is an issue of strategic importance to organizations and having significance to employees especially for women employees in terms of job satisfaction. Organizational awareness and action with respect to implementing job satisfaction and work life balance strategies hinges on an Organization's need to attract and retain valued employees in a highly competitive labour market.

The purpose of this research is to study the working environment and women's perception about the work life balance and job satisfaction, who are working in banking and education sector. Apart from it, another significant objective is to study effects of work life balance on job satisfaction and initiatives taken by the organizations for effective work life balance and its relation with the job satisfaction. To fulfill the purpose of our research study a comparative study is conducted among the working women of some Govt. colleges and national institutes of Bhopal for education sector and nationalized banks running their branches at Bhopal (M.P.) for banking sector. The concept of job satisfaction and balancing work and life is important in more than one way. There can be many factors affecting the satisfaction and balance of work and life, which may be social factors, psychological factors, Working Environment, Type of job, Job satisfaction, Family background, schedule at home and life stage.

It is obvious that employees play critical role in determining the efficiency, effectiveness and sustainability of any organization. It is paramount to understand what motivates them and to what extent they are satisfied by the organization and other contextual variables. The employee, who is able to maintain balance between private and professional life and having a high degree of job satisfaction, can contribute more to success of the organization.

\section{REVIEW OF LITERATURE}

Few studies are conducted in the area of the present study. A review of these studies provides the direction to the present study.

Alam Sageer, Dr. Sameena Rafat, Ms. Puja Agarwal (2012) studied various variables that are responsible for employee satisfaction such as Organization development, Job security, Work task, Policies of compensation and benefit and opportunities etc. The Study concluded that an organization should develop strategies that strengthen the work environment and increase the employee morale and employee satisfaction to enhance employee performance and productivity, which ultimately results in high profits, customer satisfaction as well as customer retention. And suggested the various ways by which one can improve employee satisfaction.

Dr. R. Anitha (2011) studied that Job satisfaction is a general attitude towards one's job, the difference between the amount of reward workers receive and the amount they believe they should receive. Employees will be more satisfied if they get what they expected, job satisfaction relates to inner feelings of workers. The main aim of this study was to analyze the satisfaction level of paper mill employees. Chi Square test and percentage analysis have been used in this study to analyze the job satisfaction of paper mill employees in Udumalpet and Palani Taluk. This study concluded and suggested that the organization may give importance to certain factors such as Canteen, rest room facilities, rewards, recognition and promotion policy, so that satisfaction of the employees may be improved further. 
Ayesha Tabassum, TasnuvaRahman and Kursia Jahan (2011) studied the work life of employees of private commercial banks in Bangladesh and found that no initiative was taken to identify whether there is any significant difference among the male and female employees of the private commercial banks in Bangladesh. Thus, the study aimed to make a comparative learning of the existing QWL between the males and females of the private commercial banks through quantitative survey on 128 male and 64 female employees. The study revealed that a significant difference exists between male and female employees QWL and in the following factors of QWL; adequate and fair compensation, flexible work schedule and job assignment, attention to job design, and employee relations.

Gururaja, Umesh Maiya, Elsa Sanatombi Devi, Anice George (2013) conducted descriptive survey among 67 nursing faculty towards their perceptions and attitude towards quality of Work-Life. It showed that majority, 58 (86.57 \%) experienced well balanced work-life, 9 (13.43 $\%)$ expressed moderately balanced work -life and none of them rated under poor work-life balance. Data regarding job satisfaction showed majority $35(52.24 \%)$ had moderate job satisfaction and $32(47.76 \%)$ had high job satisfaction. The correlation between work life balance and job satisfaction showed positive correlation $(r=0.77)$ which can be inferred saying that high quality of work life balance will improve job satisfaction and vice versa. This study has concluded that the work-life balance and job satisfaction are directly linked. Satisfaction in one's own area of work can lead to a satisfying career.

The purpose of Jaime X. Castillo and Jamie Cano's (2004) study was to describe the amount of variance in faculty member's overall level of job satisfaction explained by Herzberg, Mausner, and Snyderman's (1959) job motivator and hygiene factors. Additionally, the study sought to investigate the suitability of one-item versus a multi-item measure of overall job satisfaction. This study concluded that the faculty was generally satisfied with their jobs. However, female faculty members were less satisfied than male faculty members. The factor "work itself" was the most motivating aspect for faculty. The least motivating aspect was "working conditions." The factors "recognition," "supervision," and "relationships" explained the variability among faculty members \& overall level of job satisfaction. The one-item measure of overall job satisfaction was not different from a multi-item measure of overall job satisfaction.

The purpose of study of Jamal Nazrul Islam, Haradhan Kumar Mohajan, Rajib Datta's (2012) was to determine that the morale and job satisfaction plays a vital role in overall performance of the employees in the workplace? The study concluded that social status, supportive colleagues and feeling secure about the job were the top three best reasons for working in the banks. It suggested that pay, decision making authority, and promotional policy were the three top priorities for improving the work environment.

The study of Khalid Latif, Muhammad Naeem Shahid, Dr. Naeem Sohail, Muhammad Shahbaz (2011), revealed influential factors contributing to job satisfaction and dissatisfaction of college teachers of district Faisalabad, Pakistan. And they examine the level of job satisfaction of teachers in public and private sector colleges. The results showed that there were significant differences in job satisfaction between public and private college teachers. Public college teaches are more satisfied with the six components (educational qualifications, nature of work, pay, job security, promotional opportunities and family \& work life balance) of job satisfaction while private college teachers were not satisfied. This study suggested that to increase the satisfaction level of teachers of private colleges a proper attention should be paid on salary, benefits and promotion opportunities and like that the employers of private sector colleges will be able to retain teachers. 
The aim of the study of Lalita Kumari (2012) was to find about the employee's perception of their work life balance policies and practices in the public sector banks. Quota sampling method was followed. Survey was conducted and data was analyzed on the basis of responses provided by 350 respondents. The findings of the study emphasized that each of the WLB factors on its own is a salient predictor of job satisfaction and there is a significant gap among the female and male respondents with job satisfaction with respect to various factors of WLB. The positive correlation indicates that job satisfaction is an important indicator of WLB. The result of study may have practical significance for human resource managers of especially banks to improve staff commitment and productivity along with designing their recruitment and retention policies.

The study of Muhammadi Sabra Nadeem, Dr. Qaisar Abbas (2009) was aimed to explore the relationship between work life conflict and job satisfaction in Pakistan. Author found that the job satisfaction is significantly negatively correlated with work to family interference and family to work interference. Job satisfaction is also found to be negatively related with stress in this research. However, the correlation of workload is positive and insignificant which shows that workload does not affect the job satisfaction of the employees in Pakistan. Findings suggested that job autonomy emerged, as having a strong and clear correlation with job satisfaction, more autonomy in a job leads to higher job satisfaction among employees.

Raj Kamal, Debashish Sengupta (2008-09) studies that the success of the bank to a large extent depends upon the coordination, synchronization and cooperation of the Bank Officers with these two very divergent entities. Through this research study an attempt has been made not only to ascertain the degree of overall job satisfaction prevailing among the Bank Officers but also to elicit officer's views on the different factors contributing to their job satisfaction, in the light of current realities. It is concluded that with the change of satisfaction determinants, level of job satisfaction also varies. It is also observed that as a person ages, his job satisfaction shows an increasing trend. With age, spiritualism of the person increases, but his alternatives for change decreases.

The aim of research of Sakthivel Rania, Kamalanabhanb \& Selvarania (2011) was to analyze the relationship between employee satisfaction and work/life balance. The construct used for this research consists of career opportunity, recognition, work tasks, payments, benefits, superior subordinate relationship, employee satisfaction, and work/life balance. This study makes a contribution to join two distinct research streams, namely employee satisfaction, and work/life balance. Findings suggest that high correlation exists between work task and employee satisfaction with a mediator variable namely work-life balance.

K. R. Sowmya and N. Panchanatham (2011) studied that the term job satisfaction has been conceptualized in many ways. Job satisfaction focuses on all the feelings that an individual has about his/her job. It has been assumed by organizational behaviour research that individuals who express high satisfaction in their jobs are likely to be more productive, have higher involvement and are less likely to resign than employees with less satisfaction. However the researcher has studied job satisfaction of employees in new private sector and select public sector banks specifically in the banking sector of the main metropolitan city Chennai. The researcher has done a factor analysis using principle component method to find out the different factors that affect the job satisfaction of banking sectors employees. The study concluded that the employees have a significant inclination towards optimistic supervisory behaviour and pleasant organizational setup and suggested that Employees must be cared for and counselled in order to increase their satisfaction level in the organization based on the aspects identified by the organizations. 
The objective of research of V. Varatharaj, S. Vasantha (2012) was to study the work life balance of working women in service sector. Work life balance entails attaining equilibrium between professional work and other activities, so that it reduces friction between official and domestic life. Work life balance enhances efficiency and thus, the productivity of an employee increases. It enhances satisfaction, in both the professional and personal lives. This paper attempts to indentify the various factor which helps to maintain work life balance among women employees in service sector. The findings of the study revealed that the majority of the women Employees feel comfortable in their work place irrespective of their trivial personal and work place irritants.

\section{RESEARCH DESIGN}

The study is a descriptive survey study. Primary data is collected through self structured questionnaire Standard Deviation is applied in this paper to check the authenticity of data given by the respondents of both the sectors. The final questionnaire Consists 19 question/ statement, each with four options.

\section{1. Objectives of the study}

- To study the working environment in Banking and Education sector for the point view of WLB \& Job satisfaction.

- To study the perception about work life balance and job satisfaction among the working women in Banking and Education sector.

- To study the effects of work life balance on job satisfaction amongst the working in Banking and Education sector.

- To study the initiative taken by the organizations for effective work life balance and its relation with the job satisfaction.

\section{2. Hypothesis}

- The working environment in Banking and Education sector is healthy.

- Working women in Banking and Education sector have positive perception about the work life balance and job satisfaction.

- The initiative taken by the organizations have positive effect on working women in Banking and Education sector.

- Work life balance has positive effect on job satisfaction among the working women in Banking and Education sector.

\section{3. Sampling plan}

\section{3. 1. Sample Unit}

Working women of some Govt. colleges and national institutes of Bhopal for education sector and for banking sector, nationalized banks running their branches in Bhopal (M.P.).

\section{3. 2. Sample Size}

150 women employees ( 75 women employees from each sector). 


\section{DATA PRESENTATION, INTERPRETATION \& ANALYSIS}

7. 1. How is the working Environment in your organization?

\begin{tabular}{|c|c|c|c|c|c|}
\hline S. No. & Opinion & $\begin{array}{c}\text { Education } \\
\text { sector }\end{array}$ & $\mathbf{( \% )}$ & $\begin{array}{c}\text { Banking } \\
\text { sector }\end{array}$ & (\%) \\
\hline 1 & Participative & 36 & 48 & 30 & 40 \\
\hline 2 & Autonomy & 23 & 30.66 & 21 & 28 \\
\hline 3 & Capricious & 09 & 12 & 13 & 17.33 \\
\hline 4 & Red Tapism & 07 & 9.33 & 11 & 14.66 \\
\hline Total & & 75 & 100 & 75 & 100 \\
\hline
\end{tabular}

From the above table it is clear that in Education sector, $48 \%$ and $30.66 \%$ said that working environment in the organization is participative and autonomy respectively and $12 \%$ and $9.33 \%$ said that it is capricious and red tapism in that order. And when it comes to Banking sector, $40 \%$ and $28 \%$ said participative and autonomy in that order and $17.33 \%$ and $14.66 \%$ said that it is capricious and red tapism respectively. The value of Co-efficient of variance depicts that working environment of banking sector is more consistent than the education sector.

7. 2. Work allotted to you is according to your preference and skills?

\begin{tabular}{|c|c|c|c|c|c|}
\hline S. No. & Opinion & $\begin{array}{c}\text { Education } \\
\text { sector }\end{array}$ & $\mathbf{( \% )}$ & $\begin{array}{c}\text { Banking } \\
\text { sector }\end{array}$ & $(\mathbf{\%})$ \\
\hline 1 & Strongly agree & 21 & 28 & 13 & 17.33 \\
\hline 2 & Agree & 38 & 50.66 & 25 & 33.33 \\
\hline 3 & Disagree & 11 & 14.66 & 20 & 26.66 \\
\hline 4 & $\begin{array}{c}\text { Strongly } \\
\text { disagree }\end{array}$ & 05 & 6.66 & 17 & 22.66 \\
\hline Total & & 75 & 100 & 75 & 100 \\
\hline
\end{tabular}

C.V. $=66.65 \quad$ C.V. $=23.47$

From the above table it is obvious that in education sector $28 \%$ were strongly agree and $50.55 \%$ were agree While $14.66 \%$ and $4 \%$ were disagree and strongly disagree respectively. And in banking sector $17.33 \%$ were strongly agree and $33.33 \%$ were agree While majority of $26.66 \%$ and $22.66 \%$ were disagree and strongly disagree respectively. The value of Coefficient of variance completely shows that the banking sector is more consistent than the banking sector in allotment of work according to skills. 
7. 3. Employees are satisfied with the policies of top management in your organization?

\begin{tabular}{|c|c|c|c|c|c|}
\hline S. No. & Opinion & $\begin{array}{c}\text { Education } \\
\text { sector }\end{array}$ & $\mathbf{( \% )}$ & $\begin{array}{c}\text { Banking } \\
\text { sector }\end{array}$ & (\%) \\
\hline 1 & Strongly agree & 16 & 21.33 & 11 & 14.66 \\
\hline 2 & Agree & 28 & 37.33 & 35 & 46.66 \\
\hline 3 & Disagree & 23 & 30.66 & 19 & 25.33 \\
\hline 4 & $\begin{array}{c}\text { Strongly } \\
\text { disagree }\end{array}$ & 08 & 10.66 & 10 & 13.33 \\
\hline Total & & 75 & 100 & 75 & 100 \\
\hline
\end{tabular}

C.V. $=40.15 \quad$ C.V. $=53.33$

From the above table it is apparent that in education sector $21.33 \%$ of respondents were strongly agree and $37.33 \%$ were agree and only $30.66 \%$ and $10.66 \%$ of respondents were disagree and strongly disagree about it respectively. And in banking sector $14.66 \%$ were strongly agree and $46.66 \%$ were agree While $25.33 \%$ and $13.33 \%$ were disagree and strongly disagree respectively. The value of Co-efficient of variance radically shows that policies of education sector are more consistent than the banking sector.

\section{4. Physical working condition and working hours in your Organization is satisfactory?}

\begin{tabular}{|c|c|c|c|c|c|}
\hline S. No. & Opinion & $\begin{array}{c}\text { Education } \\
\text { sector }\end{array}$ & $\mathbf{( \% )}$ & $\begin{array}{c}\text { Banking } \\
\text { sector }\end{array}$ & (\%) \\
\hline 1 & Strongly agree & 10 & 13.33 & 21 & 28 \\
\hline 2 & Agree & 19 & 25.33 & 29 & 38.66 \\
\hline 3 & Disagree & 39 & 52 & 17 & 22.66 \\
\hline 4 & $\begin{array}{c}\text { Strongly } \\
\text { disagree }\end{array}$ & 07 & 9.33 & 08 & 10.66 \\
\hline Total & & 75 & 100 & 75 & 100 \\
\hline
\end{tabular}

C.V. $=66.61 \quad$ C.V. $=40.32$

From the above table it is understandable that in education sector $13.33 \%$ were strongly agree and $25.33 \%$ were agree While $52 \%$ and $9.33 \%$ were disagree and strongly disagree respectively. And in banking sector $28 \%$ were strongly agree and $29 \%$ were agree While majority of $17 \%$ and $8 \%$ were disagree and strongly disagree respectively. The value of Coefficient of variance completely shows that physical working conditions in banking sector are more consistent than the education sector.

\subsection{Interpersonal relationship among the people in your organization is satisfactory?}

From the above table it is clear that in education sector $25.33 \%$ of respondents were strongly agree and $45.33 \%$ were agree and only $21.33 \%$ and $8 \%$ of respondents were disagree 
and strongly disagree about it respectively. And in banking sector $16 \%$ were strongly agree and $33.33 \%$ were agree While $45.33 \%$ and $5.33 \%$ were disagree and strongly disagree respectively. The value of Co-efficient of variance radically shows that interpersonal relationship in sector is more consistent than the banking sector.

\begin{tabular}{|c|c|c|c|c|c|}
\hline S. No. & Opinion & $\begin{array}{c}\text { Education } \\
\text { sector }\end{array}$ & $\mathbf{( \% )}$ & $\begin{array}{c}\text { Banking } \\
\text { sector }\end{array}$ & $(\mathbf{\% )}$ \\
\hline 1 & Strongly agree & 19 & 25.33 & 12 & 16 \\
\hline 2 & Agree & 34 & 45.33 & 25 & 33.33 \\
\hline 3 & Disagree & 16 & 21.33 & 34 & 45.33 \\
\hline 4 & $\begin{array}{c}\text { Strongly } \\
\text { disagree }\end{array}$ & 06 & 8 & 04 & 5.33 \\
\hline Total & & 75 & 100 & 75 & 100 \\
\hline
\end{tabular}

C.V. $=53.51 \quad$ C.V. $=61.65$

\section{6. Employees in the organization have necessary authority to perform their duties effectively?}

\begin{tabular}{|c|c|c|c|c|c|}
\hline S. No. & Opinion & $\begin{array}{c}\text { Education } \\
\text { sector }\end{array}$ & $\mathbf{( \% )}$ & $\begin{array}{c}\text { Banking } \\
\text { sector }\end{array}$ & $(\mathbf{\% )}$ \\
\hline 1 & Strongly agree & 12 & 16 & 09 & 12 \\
\hline 2 & Agree & 24 & 32 & 29 & 38.66 \\
\hline 3 & Disagree & 26 & 34.66 & 36 & 48 \\
\hline 4 & $\begin{array}{c}\text { Strongly } \\
\text { disagree }\end{array}$ & 13 & 17.33 & 01 & 1.33 \\
\hline Total & & 75 & 100 & 75 & 100 \\
\hline
\end{tabular}

C.V. $=33.22 \quad$ C.V. $=76$

From the above table it is apparent that in education sector $16 \%$ were strongly agree and $32 \%$ were agree While $34.66 \%$ and $17.33 \%$ were disagree and strongly disagree respectively. And in banking sector $12 \%$ were strongly agree and $38.66 \%$ were agree While majority of 48 $\%$ and $1.33 \%$ were disagree and strongly disagree respectively. The value of Co-efficient of variance completely shows that education sector is more consistent than the banking sector when it comes to authority to perform duties.

\section{7. Your organization has good career prospect for its employees?}

From the above table it is apparent that in education sector $26.66 \%$ of respondents were strongly agree and $42.33 \%$ were agree and only $16 \%$ and $14.66 \%$ of respondents were disagree and strongly disagree about irrespectively. And in banking sector $20 \%$ were strongly agree and $32 \%$ were agree While $41.33 \%$ and $6.66 \%$ were disagree and strongly disagree respectively. The value of Co-efficient of variance radically shows that education sector is more consistent than the banking sector when it comes to good career prospects for its employees. 


\begin{tabular}{|c|c|c|c|c|c|}
\hline S. No. & Opinion & $\begin{array}{c}\text { Education } \\
\text { sector }\end{array}$ & $\mathbf{( \% )}$ & $\begin{array}{c}\text { Banking } \\
\text { sector }\end{array}$ & $(\mathbf{\%})$ \\
\hline 1 & Strongly agree & 20 & 26.66 & 15 & 20 \\
\hline 2 & Agree & 32 & 42.33 & 24 & 32 \\
\hline 3 & Disagree & 12 & 16 & 31 & 41.33 \\
\hline 4 & $\begin{array}{c}\text { Strongly } \\
\text { disagree }\end{array}$ & 11 & 14.66 & 05 & 6.66 \\
\hline Total & & 75 & 100 & 75 & 100 \\
\hline
\end{tabular}

C.V. $=44.8 \quad$ C.V. $=52.05$

7. 8. Counselling programs for the employees are organized by the organization regularly?

\begin{tabular}{|c|c|c|c|c|c|}
\hline S. No. & Opinion & $\begin{array}{c}\text { Education } \\
\text { sector }\end{array}$ & $\mathbf{( \% )}$ & $\begin{array}{c}\text { Banking } \\
\text { sector }\end{array}$ & $(\mathbf{\%})$ \\
\hline 1 & Strongly agree & 09 & 12 & 14 & 18.66 \\
\hline 2 & Agree & 21 & 28 & 23 & 30.66 \\
\hline 3 & Disagree & 32 & 42.66 & 28 & 37.33 \\
\hline 4 & $\begin{array}{c}\text { Strongly } \\
\text { disagree }\end{array}$ & 13 & 17.33 & 10 & 13.33 \\
\hline Total & & 75 & 100 & 75 & 100 \\
\hline
\end{tabular}

C.V. $=46.88 \quad$ C.V. $=37.55$

From the above table it is understandable that in education sector $12 \%$ were strongly agree and $28 \%$ were agree While $42.66 \%$ and $17.33 \%$ were disagree and strongly disagree respectively. And in banking sector $18.66 \%$ were strongly agree and $30.66 \%$ were agree While majority of $37.33 \%$ and $13.33 \%$ were disagree and strongly disagree respectively. The value of Co-efficient of variance completely shows that banking sector is more consistent than the education sector in organizing counselling programs within regular time interval.

\section{9. Employees in your Organization share experience to help each other?}

From the above table it is clear that in education sector $28 \%$ of respondents were strongly agree and $48 \%$ were agree and only $13.33 \%$ and $10.66 \%$ of respondents were disagree and strongly disagree about it respectively. And in banking sector $17.33 \%$ were strongly agree and $34.66 \%$ were agree While $37.33 \%$ and $10.66 \%$ were disagree and strongly disagree respectively. The value of Co-efficient of variance radically shows that banking sector is more consistent than the education sector when it comes to share experiences among the employees. 


\begin{tabular}{|c|c|c|c|c|c|}
\hline S. No. & Opinion & $\begin{array}{c}\text { Education } \\
\text { sector }\end{array}$ & $\mathbf{( \% )}$ & $\begin{array}{c}\text { Banking } \\
\text { sector }\end{array}$ & $\mathbf{( \% )}$ \\
\hline 1 & Strongly agree & 21 & 28 & 13 & 17.33 \\
\hline 2 & Agree & 36 & 48 & 26 & 34.66 \\
\hline 3 & Disagree & 10 & 13.33 & 28 & 37.33 \\
\hline 4 & $\begin{array}{c}\text { Strongly } \\
\text { disagree }\end{array}$ & 08 & 10.66 & 08 & 10.66 \\
\hline Total & & 75 & 100 & 75 & 100 \\
\hline
\end{tabular}

C.V. $=59.52 \quad$ C.V. $=45.55$

7. 10. Employees have more pressure of work in the organization or it is evenly distributed?

\begin{tabular}{|c|c|c|c|c|c|}
\hline S. No. & Opinion & $\begin{array}{c}\text { Education } \\
\text { sector }\end{array}$ & $\mathbf{( \% )}$ & $\begin{array}{c}\text { Banking } \\
\text { sector }\end{array}$ & $(\mathbf{\%})$ \\
\hline 1 & Have Pressure & 15 & 20 & 30 & 40 \\
\hline 2 & Evenly distributed & 31 & 41.33 & 12 & 16 \\
\hline 3 & $\begin{array}{c}\text { Depends on the } \\
\text { situation }\end{array}$ & 12 & 16 & 21 & 28 \\
\hline 4 & All of the above & 17 & 22.66 & 12 & 16 \\
\hline Total & & 75 & 100 & 75 & 100 \\
\hline
\end{tabular}

C.V. $=38.88 \quad$ C.V. $=39.79$

From the above table it is understandable that in education sector $20 \%$ were strongly agree and $41.33 \%$ were agree While $16 \%$ and $22.66 \%$ were disagree and strongly disagree respectively. And in banking sector $40 \%$ were strongly agree and $16 \%$ were agree While majority of $28 \%$ and $16 \%$ were disagree and strongly disagree respectively. The value of Coefficient of variance completely shows that education sector is more consistent than the banking sector at the time of distributing a work among the employees.

7. 11. Policy for work Life Balance helps in increasing productivity and satisfaction?

\begin{tabular}{|c|c|c|c|c|c|}
\hline S. No. & Opinion & $\begin{array}{c}\text { Education } \\
\text { sector }\end{array}$ & $\mathbf{( \% )}$ & $\begin{array}{c}\text { Banking } \\
\text { sector }\end{array}$ & $(\mathbf{\% )}$ \\
\hline 1 & Strongly agree & 21 & 28 & 26 & 34.66 \\
\hline 2 & Agree & 39 & 52 & 34 & 45.33 \\
\hline 3 & Disagree & 10 & 13.33 & 08 & 10.66 \\
\hline 4 & $\begin{array}{c}\text { Strongly } \\
\text { disagree }\end{array}$ & 05 & 6.66 & 07 & 9.33 \\
\hline Total & & 75 & 100 & 75 & 100 \\
\hline
\end{tabular}

C.V. $=69.6 \quad$ C.V. $=62.65$ 
From the above table it is apparent that in education sector $28 \%$ of respondents were strongly agree and $52 \%$ were agree and only $13.33 \%$ and $6.66 \%$ of respondents were disagree and strongly disagree about it respectively. And in banking sector $34.66 \%$ were strongly agree and $45.33 \%$ were agree While $10.66 \%$ and $9.33 \%$ were disagree and strongly disagree respectively. The value of Co-efficient of variance radically shows that banking sector is having a consistent work life balance policies to increase job satisfaction than the education sector.

7. 12. Welfare facilities provided by the organization to the employees are satisfactory?

\begin{tabular}{|c|c|c|c|c|c|}
\hline S. No. & Opinion & $\begin{array}{c}\text { Education } \\
\text { sector }\end{array}$ & $\mathbf{( \% )}$ & $\begin{array}{c}\text { Banking } \\
\text { sector }\end{array}$ & (\%) \\
\hline 1 & Strongly agree & 15 & 20 & 22 & 29.33 \\
\hline 2 & Agree & 22 & 29.33 & 26 & 34.66 \\
\hline 3 & Disagree & 29 & 38.66 & 19 & 25.33 \\
\hline 4 & $\begin{array}{c}\text { Strongly } \\
\text { disagree }\end{array}$ & 09 & 12 & 08 & 10.66 \\
\hline Total & & 75 & 100 & 75 & 100 \\
\hline
\end{tabular}

C.V. $=39.73 \quad$ C.V. $=35.63$

When From the above table it is obvious that in education sector $20 \%$ were strongly agree and $29.33 \%$ were agree While $38.66 \%$ and $12 \%$ were disagree and strongly disagree respectively. And in banking sector $29.33 \%$ were strongly agree and $34.66 \%$ were agree While majority of $25.33 \%$ and $10.66 \%$ were disagree and strongly disagree respectively. The value of Co-efficient of variance completely shows that banking sector is more consistent than the education sector in providing welfare facilities to its employees.

\section{13. Organization is able to retain its employees due to efficient organizational and work life balance policy?}

\begin{tabular}{|c|c|c|c|c|c|}
\hline S. No. & Opinion & $\begin{array}{c}\text { Education } \\
\text { sector }\end{array}$ & $\mathbf{( \% )}$ & $\begin{array}{c}\text { Banking } \\
\text { sector }\end{array}$ & $(\mathbf{\% )}$ \\
\hline 1 & Strongly agree & 17 & 22.66 & 15 & 20 \\
\hline 2 & Agree & 32 & 42.66 & 26 & 34.66 \\
\hline 3 & Disagree & 19 & 25.33 & 24 & 32 \\
\hline 4 & $\begin{array}{c}\text { Strongly } \\
\text { disagree }\end{array}$ & 07 & 9.33 & 10 & 13.33 \\
\hline Total & & 75 & 100 & 75 & 100 \\
\hline
\end{tabular}

C.V. $=47.04 \quad$ C.V. $=34.83$

From the above table it is clear that in education sector $22.66 \%$ of respondents were strongly agree and $42.66 \%$ were agree and only $25.33 \%$ and $9.33 \%$ of respondents were disagree and strongly disagree about it respectively. And in banking sector $20 \%$ were strongly agree and $34.66 \%$ were agree While $32 \%$ and $13.33 \%$ were disagree and strongly disagree 
respectively. The value of Co-efficient of variance radically shows that banking sector is more consistent than the education sector in retaining the employees through effective work life balance policies.

7. 14. Do you think that if employees have good work-life balance then they will be satisfied by the job?

\begin{tabular}{|c|c|c|c|c|c|}
\hline S. No. & Opinion & $\begin{array}{c}\text { Education } \\
\text { sector }\end{array}$ & $\mathbf{( \% )}$ & $\begin{array}{c}\text { Banking } \\
\text { sector }\end{array}$ & (\%) \\
\hline 1 & Strongly agree & 19 & 25.33 & 22 & 29.33 \\
\hline 2 & Agree & 40 & 53.33 & 39 & 52 \\
\hline 3 & Disagree & 11 & 14.66 & 08 & 10.66 \\
\hline 4 & $\begin{array}{c}\text { Strongly } \\
\text { disagree }\end{array}$ & 05 & 6.66 & 06 & 8 \\
\hline Total & & 75 & 100 & 75 & 100 \\
\hline
\end{tabular}

C.V. $=70.61$

C.V. $=\mathbf{7 0 . 5 0}$

From the above table it is apparent that in education sector $25.33 \%$ were strongly agree and $53.33 \%$ were agree While $14.66 \%$ and $6.66 \%$ were disagree and strongly disagree respectively. And in banking sector $29.33 \%$ were strongly agree and $52 \%$ were agree While majority of $10.66 \%$ and $8 \%$ were disagree and strongly disagree respectively. The value of Co-efficient of variance completely shows that working women from both the sector are agree that having a good work life balance is a key to job satisfaction.

7. 15. I feel comfortable in discussing changes regarding work and working arrangements with my superior?

\begin{tabular}{|c|c|c|c|c|c|}
\hline S. No. & Opinion & $\begin{array}{c}\text { Education } \\
\text { sector }\end{array}$ & $\mathbf{( \% )}$ & $\begin{array}{c}\text { Banking } \\
\text { sector }\end{array}$ & $(\mathbf{\%})$ \\
\hline 1 & Strongly agree & 15 & 20 & 18 & 24 \\
\hline 2 & Agree & 26 & 34.66 & 21 & 28 \\
\hline 3 & Disagree & 21 & 28 & 24 & 32 \\
\hline 4 & $\begin{array}{c}\text { Strongly } \\
\text { disagree }\end{array}$ & 13 & 17.33 & 12 & 16 \\
\hline Total & & 75 & 100 & 75 & 100 \\
\hline
\end{tabular}

C.V. $=27.30$

From the above table it is understandable that in education sector $20 \%$ of respondents were strongly agree and $34.66 \%$ were agree and only $28 \%$ and $17.33 \%$ of respondents were disagree and strongly disagree about it respectively. And in banking sector $24 \%$ were strongly agree and $28 \%$ were agree While $32 \%$ and $16 \%$ were disagree and strongly disagree respectively. The value of Co-efficient of variance radically shows that banking sector is more consistent than the education sector in making flexible working arrangements. 
7. 16. Your organization takes initiative to manage work and work life of its employees?

\begin{tabular}{|c|c|c|c|c|c|}
\hline S. No. & Opinion & $\begin{array}{c}\text { Education } \\
\text { sector }\end{array}$ & $\mathbf{( \% )}$ & $\begin{array}{c}\text { Banking } \\
\text { sector }\end{array}$ & (\%) \\
\hline 1 & Never & 12 & 16 & 11 & 14.66 \\
\hline 2 & Sometimes & 24 & 32 & 19 & 25.33 \\
\hline 3 & Often & 15 & 20 & 12 & 16 \\
\hline 4 & Always & 24 & 32 & 33 & 44 \\
\hline Total & & 75 & 100 & 75 & 100 \\
\hline
\end{tabular}

C.V. $=\mathbf{2 8 . 5 9}$

C.V. $=46.88$

From the above table it is clear that in education sector $16 \%$ were strongly agree and $32 \%$ were agree While $20 \%$ and $32 \%$ were disagree and strongly disagree respectively. And in banking sector $14.66 \%$ were strongly agree and $25.33 \%$ were agree While majority of $16 \%$ and $44 \%$ were disagree and strongly disagree respectively. The value of Co-efficient of variance completely shows that education sector is more consistent in taking initiative to manage work and work life balance than the banking sector.

7. 17. Request to change work and working patterns are positively received by the superiors?

\begin{tabular}{|c|c|c|c|c|c|}
\hline S. No. & Opinion & $\begin{array}{c}\text { Education } \\
\text { sector }\end{array}$ & $\mathbf{( \% )}$ & $\begin{array}{c}\text { Banking } \\
\text { sector }\end{array}$ & $(\mathbf{\% )}$ \\
\hline 1 & Strongly agree & 11 & 14.66 & 10 & 13.33 \\
\hline 2 & Agree & 25 & 33.33 & 21 & 28 \\
\hline 3 & Disagree & 29 & 38.66 & 33 & 44 \\
\hline 4 & $\begin{array}{c}\text { Strongly } \\
\text { disagree }\end{array}$ & 10 & 13.33 & 11 & 14.66 \\
\hline Total & & 75 & 100 & 75 & 100 \\
\hline
\end{tabular}

C.V. $=44.69 \quad$ C.V. $=53.92$

From the above table it is clear that in education sector $14.66 \%$ of respondents were strongly agree and $33.33 \%$ were agree and only $38.66 \%$ and $13.33 \%$ of respondents were disagree and strongly disagree about it respectively. And in banking sector $13.33 \%$ were strongly agree and $28 \%$ were agree While $44 \%$ and $14.66 \%$ were disagree and strongly disagree respectively. The value of Co-efficient of variance radically shows that education sector is more consistent than the banking sector when it comes to getting co-operation from superiors sometimes. 
7. 18. Your organization provides satisfactory compensation or non monetary rewards according to the Work?

\begin{tabular}{|c|c|c|c|c|c|}
\hline S. No. & Opinion & $\begin{array}{c}\text { Education } \\
\text { sector }\end{array}$ & $\mathbf{( \% )}$ & $\begin{array}{c}\text { Banking } \\
\text { sector }\end{array}$ & $\mathbf{( \% )}$ \\
\hline 1 & Strongly agree & 15 & 20 & 13 & 17.33 \\
\hline 2 & Agree & 29 & 38.66 & 32 & 42.66 \\
\hline 3 & Disagree & 20 & 26.66 & 21 & 28 \\
\hline 4 & $\begin{array}{c}\text { Strongly } \\
\text { disagree }\end{array}$ & 11 & 14.66 & 09 & 12 \\
\hline Total & & 75 & 100 & 75 & 100 \\
\hline
\end{tabular}

C.V. $=35.84$

C.V. $=46.88$

From the above table it is understandable that in education sector $20 \%$ were strongly agree and $38.66 \%$ were agree While $26.66 \%$ and $14.66 \%$ were disagree and strongly disagree respectively. And in banking sector $17.33 \%$ were strongly agree and $42.66 \%$ were agree While majority of $28 \%$ and $12 \%$ were disagree and strongly disagree respectively. The value of Coefficient of variance completely shows that education sector is more consistent than the banking sector when it comes to getting non monetary rewards according to the Work.

7. 19. Management is committed in helping employees to achieve a good work-life balance and satisfaction from work?

\begin{tabular}{|c|c|c|c|c|c|}
\hline S. No. & Opinion & $\begin{array}{c}\text { Education } \\
\text { sector }\end{array}$ & $\mathbf{( \% )}$ & $\begin{array}{c}\text { Banking } \\
\text { sector }\end{array}$ & $(\mathbf{\% )}$ \\
\hline 1 & Strongly agree & 12 & 16 & 15 & 20 \\
\hline 2 & Agree & 31 & 41.33 & 34 & 45.33 \\
\hline 3 & Disagree & 19 & 25.33 & 14 & 18.66 \\
\hline 4 & $\begin{array}{c}\text { Strongly } \\
\text { disagree }\end{array}$ & 13 & 17.33 & 12 & 16 \\
\hline Total & & 75 & 100 & 75 & 100 \\
\hline
\end{tabular}

C.V. $=40.32 \quad$ C.V. $=47.36$

From the above table it is clear that in education sector $16 \%$ of respondents were strongly agree and $41.33 \%$ were agree and only $25.33 \%$ and $17.33 \%$ of respondents were disagree and strongly disagree about it respectively. And in banking sector $20 \%$ were strongly agree and $45.33 \%$ were agree While $18.66 \%$ and $16 \%$ were disagree and strongly disagree respectively. The value of Co-efficient of variance radically shows that management of education sector is more consistent and committed to achieve a good work-life balance and satisfaction from work than the banking sector. 


\section{FINDINGS}

- Overall the working women are quite satisfied and view that somewhat they look education sector as a good place to work than the banking sector.

- Employees of both the sector report an average level of work life balance and are generally happy with their working arrangements.

- Most of the working women found participative environment in the education sector than the banking sector.

- Job satisfaction affects employee morale, turnover, absenteeism, and pro-social behavior, which can be crucial for organizational success.

- There is a feeling that employers are investing in work-life balance, but the somewhat in education sector 'solutions' offered are not always compatible with employee's needs.

- Working in an environment where employees share the experience and having mutual respect was also important to the employees for job satisfaction.

- $34 \%$ of employees in education sector and $45 \%$ of employees in banking sector feel that they are not always making well-informed decisions about their own work-life balance.

- It is found that in banking sector that most of the employees agree that they are physically stressed in their job and in education sector some of the Employees strongly agree that they are mentally pressurized in their job.

- Somewhere employers do not adequately and transparently communicate about work-life balance.

- Majority of the employees in education sector agree that their superiors are more helpful and cooperative which may be one of the reasons for job satisfaction.

- WLB is an important determinant of intrinsic aspects of job satisfaction.

- It is found that employees are more committed towards their job to get higher reward and appreciation. This attitude towards their jobs however increases family conflict but increases job satisfaction.

- If the employees are given freedom to choose their own work schedules; quality and productivity of the work increases. Because if this opportunity given to the employee so it will also bring to the responsibility for finishing work within specified deadline.

- Most of the employees in education sector agree that work allotment is based on skills and qualification but women in banking sector did not agree on this statement.

- It is found that most of the women employees enjoy the job and feel comfortable at their work place. This might be the reason for the growth of women employees at the working place in banking sector.

- Authority to perform duties effectively is another factor of job satisfaction.

- The research shows that women employees work in banks for financial support generally faces life challenges than the education sector.

- High quality of work life balance will improve the job satisfaction and vice versa.

- Working hours are satisfactory but sometimes late working and working in evening branches in banks interrupts work life balance.

\section{CONCLUSIONS}

Work life balance and job satisfaction is not a problem to be solved. These are ongoing issues to be managed. Both are not impossible, but it does take some consistent effort and 
revaluation on an on going basis. Work can dominate your life. Recognizing what is important and necessary and striving for what is valued will make a work-life balance feasible. Utilizing management skills will enable you to have a job satisfaction and balance between work and home life. There are many causes for stress in the workplace and the possibility for eliminating all of them is impossible. It also may be harmful. Sometimes stress provides positive outcomes. Stress can sometimes motivate and refresh and enable people to achieve more; the key appears to be in how individuals are able to cope with it. Both the sector can help working women by implementing organizational strategies to control or reduce some of the major causes of stress. It could be said that with the change of satisfaction determinants, level of job satisfaction also varies. For the employers, Work-life balance and Job satisfaction of employees will be an important input in designing appropriate policies for employees to address work - life balance and job satisfaction issues.

\section{SUGGESTIONS}

- The employee feels that the work-loads are not equal between colleagues. So equal distribution of workloads should be done to improve the satisfaction of employee especially in the banking sector.

- Although the female respondents agreed with banks WLB policies but they disagreed with overall WLB. So the female employees should be given the facilities like flexible time; job sharing; crèche facilities, and necessary breaks so that they feel that the organization is helping them in coordinating the family and professional life.

- An ideal work culture in education sector can be created to achieve job satisfaction. To improve the work environment following ideas should be adopted: More cordial co-workers, more cohesiveness between departments, trust and open communication, having a lighter workload, less red tape, more training opportunities, having better office and wash area facilities, easier access to new technology etc.

- WLB improve the productivity and eliminate job stress, employers can also make efforts to know the workload and job demands.

- Open the lines of communication between administration, Board members, Trade union, and Employees as they all should be interested in the common goal of improving productivity and performance of the organization.

- The management of both the sectors should take steps toward improving the morale of the employees by implementing organizational strategies that would enhance the work culture.

- Employees of education sector should receive acknowledgement for their outstanding efforts, this can be conducted in the form of continuous appraisals, staff awards or creating an innovative reward system that will heighten their morale and at the same time acknowledge their good performance.

- Banks should introduce job sharing option in which full-time post is split across two workers who agree on working hours decided in between them and career breaks (paid/unpaid).

- Somewhere in banking sector employees are dissatisfied or resist the change. So some workshops on motivating staff on the reason for change should be done. And the economical benefits associated with change as well as how staff would benefit from these changes should be communicated properly.

- It's also recommended that when management communicates the policies and procedures of the organization, they should come through as transparent, positive and optimistic. 
- As it shows that different age groups have different perceptions regarding WLB, so work should be distributed according to the age and qualification. It will improve the employee's commitment and satisfaction level along with productivity and profitability.

- Since team work impacts very positively in achieving the goals and the mission of the organization. So proper consideration should be given on individual as well as team rewards.

- Work life imbalance is another reason of job dissatisfaction. So, a supportive management is required to minimize the conflict between work and family. Top management of both the sector should realize the importance of work life balance and its adverse affect on job satisfaction.

- Bank should have formal counseling department to understand the workers work life balance problems and to help the workers to get the solution.

- Initiate and engage discussion with workers using social media to understand their work life balance needs and aspirations.

- Certain modern techniques like Yoga, Instrumental activities should be included in organization to reduce the job stress in both the sectors.

- Employees' social gathering programs and public contact programs will be the better option to reduce the mental pressure in the work place as the study reveals more mental pressure for the Women employees.

- In the banking sector, there must be brain storming between employees and employers relating to their job profile, job stress, and salary from time to time in order to increase their job-commitment.

- Ensure fairness and consistency in the way bank policies that support work-life balance are implemented.

- Reward and recognition system should be fair and transparently to be adapted to each and every employee in the Organization in both the sectors.

- Nonfinancial rewards often have more impact than financial reorganization in attaining job satisfaction and managing life in education sector.

\section{References}

[1] Sageer A., Rafat S., Agarwal P. (2012). "Identification of Variables Affecting Employee Satisfaction and Their Impact on the Organization", IOSR Journal of Business and Management, Volume 5, Issue 1, pp: 32-39.

[2] Anitha R. (2011), “A study on job satisfaction of paper mill employees with special reference to Udumalpet and PalaniTaluk", Journal of Management and Science, Vol. 1, No.1, Sep 2011, pp. 36-47.

[3] Tabassum A., Rahman T., Jahan K. (2011). "Quality of Work Life among Male and Female Employees of Private Commercial Banks in Bangladesh", Int. Journal of Economics and Management, Vol.5 (1), pp: 266-282.

[4] Gururaja U. Maiya E. S., Devi A. George (2013). "Perceptions and Attitude towards Quality of Work-life Balance among nursing teachers", International Journal of Humanities and Social Science Invention, Volume: 2, Issue: 3, pp. 52-54.

[5] Castillo J. X., Cano J. (2004). "Factors explaining job satisfaction among faculty, Journal of Agricultural Education", Volume 45, Number 3, pp. 65-74. 
[6] Islam J. N., Mohajan H. K. and Datta R. (2012). "A Study on Job Satisfaction and Morale of Commercial Banks in Bangladesh”, IJER, Jul - Aug, pp: 153-173.

[7] Latif K., Shahid M. N., Sohail N., Shahbaz M. (2011). "Job Satisfaction among Public and Private College Teachers of District Faisalabad, Pakistan: A Comparative Analysis", Interdisciplinary Journal of Contemporary Research in Business, Vol. 3, No 8, pp: 235-242.

[8] Kothari C. R. (2004). "Research methodology - methods and techniques", new age international publishers, pp. 233-238.

[9] Kumari L. (2012). “Employees Perception on Work Life Balance and its Relation with Job Satisfaction in Indian Public Sector Banks", IJEMR, Vol. 2, Issue: 2, pp. 1-13.

[10] Nadeem M. S. (2009). "The Impact of Work Life Conflict on Job Satisfactions of Employees in Pakistan", International Journal of Business and Management, Vol. 4, No. 5, pp. 63-83.

[11] Kamal R., Sengupta D. (2008-09). “A Study of Job Satisfaction of Bank Officers", Prajnan, Vol. XXXVII, No. 3, pp: 229-245.

[12] Rao VSP (2009), "Human resource management - Text and cases", Excel books - New Delhi, pp. 299-306.

[13] Rania S., Kamalanabhanb \& Selvarania, (2011). Work / Life Balance Reflections on Employee Satisfaction, Serbian Journal of Management, Vol. 6 (1), pp. 85-96.

[14] Sowmya K. R. and Panchanatham N. (2011). "Factors influencing job satisfaction of banking sector employees in Chennai, India", Journal of Law and Conflict Resolution, Vol. 3(5), pp. 76-79.

[15] Varatharaj V., Vasantha S. (2012). Work Life Balances A Source Of Job Satisfaction An Exploratory Study On The View Of Women Employees In The Service Sector, International Journal of Multidisciplinary Research, Vol.2 Issue 3, pp. 450-458.

[16] Rajesh K. Yadav, Nishant Dabhade, International Letters of Social and Humanistic Sciences 7 (2013) 1-22.

[17] Rajesh K. Yadav, Nishant Dabhade, International Letters of Social and Humanistic Sciences 8 (2013) 77-85.

[18] Rajesh K. Yadav, Nishant Dabhade, International Letters of Social and Humanistic Sciences 5 (2014) 44-62.

[19] M. Shoukat Malik, Muhammad Nadeem, International Letters of Social and Humanistic Sciences 10(1) (2014) 9-19.

[20] Nadeem Iqbal, Naveed Ahmad, Zeeshan Riaz, International Letters of Social and Humanistic Sciences 9 (2014) 14-25. 